\title{
Molecular characterization of organic aerosol in the Himalayas: insight from ultra-high-resolution mass spectrometry
}

\author{
Yanqing An ${ }^{1}$, Jianzhong $\mathrm{Xu}^{1}$, Lin Feng ${ }^{1,3}$, Xinghua Zhang ${ }^{1,3}$, Yanmei Liu ${ }^{1,3}$, Shichang Kang ${ }^{1}$, Bin Jiang ${ }^{2}$, and \\ Yuhong Liao ${ }^{2}$ \\ ${ }^{1}$ State Key Laboratory of Cryospheric Science, Northwest Institute of Eco-Environment and Resources, \\ Chinese Academy of Sciences, Lanzhou 730000, China \\ ${ }^{2}$ State Key Laboratory of Organic Geochemistry, Guangzhou Institute of Geochemistry, \\ Chinese Academy of Sciences, Guangzhou 510640, China \\ ${ }^{3}$ University of Chinese Academy of Sciences (UCAS), Beijing 100049, China
}

Correspondence: Jianzhong Xu (jzxu@lzb.ac.cn)

Received: 7 July 2018 - Discussion started: 20 August 2018

Revised: 28 November 2018 - Accepted: 8 January 2019 - Published: 29 January 2019

\begin{abstract}
An increased trend in aerosol concentration has been observed in the Himalayas in recent years, but the understanding of the chemical composition and sources of aerosol remains poorly understood. In this study, molecular chemical composition of water-soluble organic matter (WSOM) from two filter samples collected during two high aerosol loading periods (denoted as P1 and P2) at a highaltitude station (Qomolangma Station, QOMS; $4276 \mathrm{~m}$ a.s.l.) in the northern Himalayas was identified using electrospray ionization Fourier transform ion cyclotron resonance mass spectrometry (ESI-FTICR MS). More than 4000 molecular formulas were identified in each filter sample which were classified into two compound groups ( $\mathrm{CHO}$ and $\mathrm{CHON}$ ) based on their elemental composition, with both accounting for nearly equal contributions in number $(45 \%-55 \%)$. The relative abundance weighted mole ratio of $\mathrm{O} / \mathrm{C}_{\mathrm{w}}$ for $\mathrm{P} 1$ and $\mathrm{P} 2$ was 0.43 and 0.39 , respectively, and the weighted double bond equivalents $\left(\mathrm{DBE}_{\mathrm{w}}\right)$, an index for the saturation of organic molecules, were 7.12 and 7.87, respectively. Although the $\mathrm{O} / \mathrm{C}_{\mathrm{w}}$ mole ratio was comparable for $\mathrm{CHO}$ and CHON compounds, the $\mathrm{DBE}_{\mathrm{w}}$ was significantly higher in CHON compounds than CHO compounds. More than $50 \%$ molecular formulas in the Van Krevelen (VK) diagram $(\mathrm{H} / \mathrm{C}$ vs. $\mathrm{O} / \mathrm{C})$ were located in $1-1.5(\mathrm{H} / \mathrm{C})$ and $0.2-0.6(\mathrm{O} / \mathrm{C}) \mathrm{re}-$ gions, suggesting potential lignin-like compounds. The distributions of $\mathrm{CHO}$ and $\mathrm{CHON}$ compounds in the VK diagram, DBE vs. number of $\mathrm{C}$ atoms, and other diagnostic diagrams showed high similarities among each other, suggest-
\end{abstract}

ing their similar source and/or atmospheric processes. Many formulas formed from biogenic volatile organic compounds (e.g., ozonolysis of $\alpha$-pinene products) and biomass-burningemitted compounds (e.g., phenolic compounds) were found in the WSOM, suggesting the important contribution of these two sources in the Himalayas. The high DBE and high fraction of nitrogen-containing aerosol can potentially impact aerosol light absorption in this remote region. Further comprehensive study is needed due to the complexity of organic aerosol and limited molecular number identified in this study.

\section{Introduction}

Relatively high aerosol concentration events have been frequently observed over the Himalayas during the premonsoon period (March to June) (Bonasoni et al., 2010). The aerosol plumes are originated from the southern regions of the Himalayas such as northwestern India and/or the IndoGangetic Plain based on air mass back trajectory analysis and satellite observation (Liu et al., 2008; Lu et al., 2012; Lüthi et al., 2015). Due to increased consumption on fuels (including biofuels and fossil fuels) by industry and residents in recent decades, air pollution has been a serious issue in south Asia (Gustafsson et al., 2009). Under favorable atmospheric circulation, air pollutants emitted or formed in these regions can be transported fast to the Himalayas and Tibetan Plateau (HTP; Xia et al., 2011). 
Enhanced aerosol concentration for the remote region of the HTP is thought to have many negative climate and environment effects. For example, the transported aerosol could heat the air in the higher layer of the troposphere over the HTP and impact the monsoon system of south Asia and accelerate the melting of glaciers in the Himalayas (Lau et al., 2006; Ramanathan et al., 2007). This heating effect is predominantly from light-absorbing particular aerosol (LAPA) such as black carbon (BC) and brown carbon which are types of organic aerosol (OA; Ram et al., 2010; Zhang et al., 2015, 2017). BC is from incomplete combustion and dominates the absorption of LAPA; brown carbon can originate from primary emission and/or secondary processes, and has made an increasing contribution (up to $\sim 20 \%$ ) to light absorption in recent years (Laskin et al., 2015, and reference therein). Due to the light absorption of brown carbon being strongly dependent on their molecular structure, light-absorbing compounds at a molecular level have been explored during recent years, and it was found that nitrogen-containing compositions are important brown carbon compounds (Lin et al., 2016, 2017). Many studies show that biomass burning is an important source of brown carbon (e.g., Saleh et al., 2014; Washenfelder et al., 2015), which is very common in developing regions in the southern Himalayas. In comparison with other regions, high elevation and mixed biomass fuels in the southern Himalayas could make the evolution and chemical composition of OA from biomass burning emission more complicated (Stockwell et al., 2016; Fleming et al., 2018; Jayarathne et al., 2018).

The details on the molecular composition of OA are important for understanding the sources and chemical evolution of OA (Laskin et al., 2018). Previous studies conducted in the HTP have focused on a limited number of molecular markers such as organic acids, which are closely related to biomass burning emission (Cong et al., 2015), and some toxicology species such as polycyclic aromatic hydrocarbons (PAHs) and persistent organic pollutants (POPs), which are related to anthropogenic activities (Wang et al., 2015, 2016). In addition, online measurement using the Aerodyne highresolution time-of-flight aerosol mass spectrometer (HRToF-AMS) has provided more details on the chemistry and sources of OA with a high time resolution (Xu et al., 2018). However, different instruments have limitations on OA detection, and an ultra-high mass resolution of mass spectrometry which can identify many molecular formulas is lacking.

Fourier transform-ion cyclotron resonance mass spectrometry (FTICR MS) coupled with a soft ionization source, such as electrospray ionization (ESI), can be used to identify the individual molecular formula of extremely complex mixtures because of its ultra-high resolution and mass accuracy (Mazzoleni et al., 2010). Similar methods have been used for the identification of components in aqueous secondary OA (SOA) and in ambient samples, and allow the identification and separation of thousands of compounds in a sample (e.g., Mazzoleni et al., 2010; Altieri et al., 2012; Mead et al., 2013).
Types of methods such as double bond equivalents (DBEs), elemental ratios, and Kendrick mass defects (KMDs) can be applied to deduce the chemical characterization of obtained molecular formulas. In this study, we focus on the molecular composition of water-soluble organic compound in fine particle aerosol in the Himalayas using ESI-FTICR MS and evaluate the sources, chemical processing, and potential impact of aerosol in this region.

\section{Methodology}

\subsection{Aerosol sampling}

A field study was conducted at the Qomolangma Station (QOMS; $28.36^{\circ} \mathrm{N}, 86.95^{\circ} \mathrm{E} ; 4276 \mathrm{~m}$ a.s.l.) located at the toe of Mt. Qomolangma from 12 April to 12 May 2016 using a suite of online instruments (X. Zhang et al., 2018), including a HR-ToF-AMS (Aerodyne Research Inc., Billerica, MA, USA) for $5 \mathrm{~min}$ size-resolved chemical compositions (organics, sulfate, nitrate, ammonium, and chloride) of non-refractory submicron particulate matter $\left(\mathrm{NR}-\mathrm{PM}_{1}\right)$ and a photoacoustic extinctiometer (PAX; DMT Inc., Boulder, $\mathrm{CO}$, USA) for BC mass concentration. In addition, a lowvolume (16.7 $\mathrm{L} \mathrm{min}^{-1}$ ) particular matter (PM) sampler (BGI, USA, model PQ 200) with an Aerodyne diameter cutoff of $2.5 \mu \mathrm{m}$ at the inlet was used to collect $\mathrm{PM}_{2.5}$ filter samples on pre-baked quartz fiber filters (47 mm, Pall Life Science, NY, USA). Due to the low aerosol loading at this remote region, a 2-day sampling strategy was adapted for each filter collection from 08:00 to 07:45 the following day (local time). A total of 18 filter samples were collected during the field study with three procedure blanks which were used to assess potential contamination during sampling and transportation. The sampling air volume ranged from 35.1 to $48.1 \mathrm{~m}^{3}$ at ambient conditions. Two samples collected during 25-27 April (P1) and 29 April-1 May (P2), respectively, were used in this study due to the relatively higher aerosol loading based on HR-ToF-AMS results (Sect. 3.1) and distinct particulate matter on the filter. One procedure blank was also adopted in this study like that of aerosol samples to subtract the potential background.

\subsection{Chemical analysis}

For FTICR MS analysis, filter samples were extracted in $20 \mathrm{~mL}$ Milli-Q water in an ultrasonic bath for $30 \mathrm{~min}$ and filtered using $0.45 \mu \mathrm{m}$ pore-size Acrodisc syringe filters to remove water-insoluble matter (Pall Science, USA). The sample tubes were immersed in the mixture of ice-water during ultrasonic extraction to prevent potential chemical reaction. Prior to FTICR MS analysis, the extraction was concentrated and purified using PPL (Agilent Bond Elut-PPL cartridges, $500 \mathrm{mg}, 6 \mathrm{~mL}$ ) solid-phase extraction (SPE) cartridges for water-soluble organic matter (WSOM) to avoid possible ESI artifacts. PPL cartridges generally have the best 
properties for WSOM enrichment for subsequent FTICR MS analysis (Raeke et al., 2016). In addition, we control the concentration of SPE effluent to be $\sim 0.2 \mathrm{mg} \mathrm{mL}^{-1}$, which was not too concentrated for artifact adducts. Note that through SPE cartridges, the most hydrophilic compounds, such as inorganic ions, and low-molecular-weight organic molecules, such as organic acids and sugars, were removed, whereas the relatively hydrophobic fraction was retained. Details on the SPE method using PPL cartridges and analysis using FT-ICR MS can be found in our previous paper (Feng et al., 2016). Briefly, the mass spectrometry analyses of these samples were performed using a SolariX XR FTICR MS (Bruker Daltonik $\mathrm{GmbH}$, Bremen, Germany) equipped with a $9.4 \mathrm{~T}$ refrigerated actively shielded superconducting magnet (Bruker Biospin, Wissembourg, France) and a Paracell analyzer cell. The samples were ionized in positive ion modes using the ESI ion source (Bruker Daltonik GmbH, Bremen, Germany). A typical mass-resolving power of $>400000$ was achieved at $m / z 400$, with an absolute mass error of $<0.5 \mathrm{ppm}$. The ions detected in filter blank were subtracted and molecular formulas in the samples were assigned to all ions with signalto-noise ratios of greater than 10 , with a mass tolerance of $\pm 1.5 \mathrm{ppm}$, using custom software. Molecular formulas with their maximum numbers of atoms were defined as $30{ }^{12} \mathrm{C}, 60$ ${ }^{1} \mathrm{H}, 20{ }^{16} \mathrm{O}, 3{ }^{14} \mathrm{~N}, 1{ }^{32} \mathrm{~S}, 1{ }^{13} \mathrm{C}, 1{ }^{18} \mathrm{O}$, and $1{ }^{34} \mathrm{~S}$. Identified formulas with $\mathrm{H} / \mathrm{C}, \mathrm{O} / \mathrm{C}, \mathrm{N} / \mathrm{C}, \mathrm{S} / \mathrm{C}$, and $\mathrm{DBE} / \mathrm{C}$, ranging $0.3-3.0,0-3,0-0.5,0-0.2$, and $0-1$, were selected, and formulas containing isotopomers (i.e., ${ }^{13} \mathrm{C},{ }^{18} \mathrm{O}$, or ${ }^{34} \mathrm{~S}$ ) were not considered. Compounds were detected as either sodium adducts, $[\mathrm{M}+\mathrm{Na}]^{+}$, or protonated species, $[\mathrm{M}+\mathrm{H}]^{+}$. Although ammonium could also readily be adduct to assist in the formation of positive ions, this possibility in our sample was because of the low concentration of ammonium (Fig. 1). We report all detected compounds as neutral species, unless stated otherwise. Note that the ESI+ mode more easily detects basic functional group compounds, and the reported organic molecules here are only part of organic aerosol which are biased ionized in ESI+ mode. In addition, highly functionalized compounds could be detected in both positive and negative modes (Lin et al., 2012).

\subsection{Data processing}

The assigned molecular formulas were examined using the Van Krevelen diagram (Wu et al., 2004), DBEs, KMD series, and aromatic indices $\left(\mathrm{AI}_{\text {mod }}\right)$. The $\mathrm{O} / \mathrm{C}$ and $\mathrm{H} / \mathrm{C}$ ratios were calculated by dividing the number of $\mathrm{O}$ and $\mathrm{H}$ atoms, respectively, by the number of $\mathrm{C}$ atoms in a formula. $\mathrm{DBE}$ analysis was used to determine the number of rings and double bonds in a molecule. The DBE was calculated using Eq. (1):

$\mathrm{DBE}=1+c-h / 2+n / 2$,

where $c, h$, and $n$ are the numbers of $\mathrm{C}, \mathrm{H}$, and $\mathrm{N}$ atoms, respectively, in the formula.

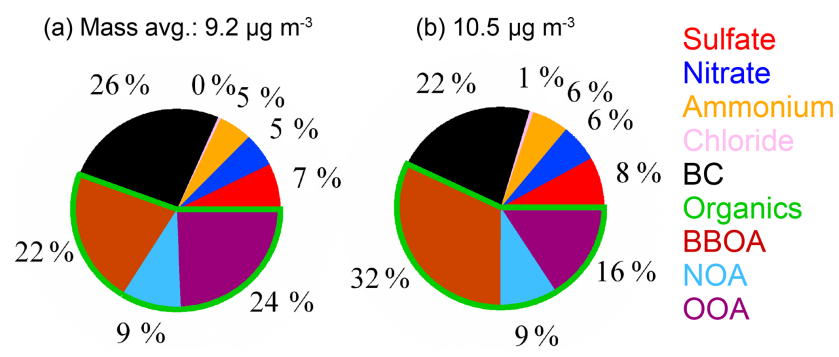

Figure 1. The average mass concentration (mass avg.) and chemical composition of $\mathrm{PM}_{1}$ during $\mathrm{P} 1$ (a) and $\mathrm{P} 2$ (b) periods, respectively, measured by the HR-ToF-AMS and PAX. Note that the compounds of $\mathrm{PM}_{1}$ include sulfate, nitrate, ammonium, chloride, $\mathrm{BC}$ (black carbon), organics, BBOA (biomass-burning-emitted OA), NOA (nitrogen-containing OA), and OOA (oxidized oxygenated OA).

The weighted DBE $\left(\mathrm{DBE}_{\mathrm{w}}\right), \mathrm{O} / \mathrm{C}\left(\mathrm{O} / \mathrm{C}_{\mathrm{w}}\right)$, and $\mathrm{H} / \mathrm{C}$ $\left(\mathrm{H} / \mathrm{C}_{\mathrm{W}}\right)$ were calculated using Eq. (2):

$X_{\mathrm{w}}=\sum\left(w_{i} \cdot X_{i}\right) / \sum w_{i}$,

where $X_{i}$ and $w_{i}$ are the parameters above and the relative intensity (RI) is for each individual formula, $i$.

The Kendrick mass (KM) and KMD for $\mathrm{CH}_{2}$ series, used to search for potential oligomeric units (Hughey et al., 2001), were calculated using Eqs. (3) and (4):

$\mathrm{KM}=$ observed mass $\times 14 / 14.01565$,

$\mathrm{KMD}=\mathrm{NM}-\mathrm{KM}$,

where 14 is the nominal mass (NM) of $\mathrm{CH}_{2}, 14.01565$ is the exact mass of $\mathrm{CH}_{2}$, and $\mathrm{NM}$ is $\mathrm{KM}$ rounded to the nearest integer.

Furthermore, a second-order mass defect analysis using the base units of $\mathrm{CH}_{2}$ and $\mathrm{H}_{2}$ was applied following the method described in Roach et al. (2011), which greatly simplified the visualization of complex mass spectra.

$\mathrm{AI}_{\text {mod }}$ is a measure of the probable aromaticity of a molecule assuming that half the $\mathrm{O}$ atoms are double bonded and half have only $\sigma$ bonds (Koch and Dittmar, 2006). AI mod was calculated using Eq. (5):

$\mathrm{AI}_{\text {mod }}=(1+c-0.5 o-0.5 h-0.5 n) /(c-0.5 o-n)$,

where $c, o$, and $h$ are the numbers of $\mathrm{C}, \mathrm{O}, \mathrm{H}$, and $\mathrm{N}$ atoms in the formula. $\mathrm{AI}_{\mathrm{mod}}$ ranges from 0 for a purely aliphatic compound to higher values for compounds with more double bonds and that are more aromatic.

\section{Results and discussions}

\subsection{Chemical characterization of $\mathrm{PM}_{1}$ during $\mathrm{P1}$ and P2 measured by the HR-ToF-AMS}

The average mass concentration and chemical composition measured by the HR-ToF-AMS during $\mathrm{P} 1$ and $\mathrm{P} 2$ periods are 

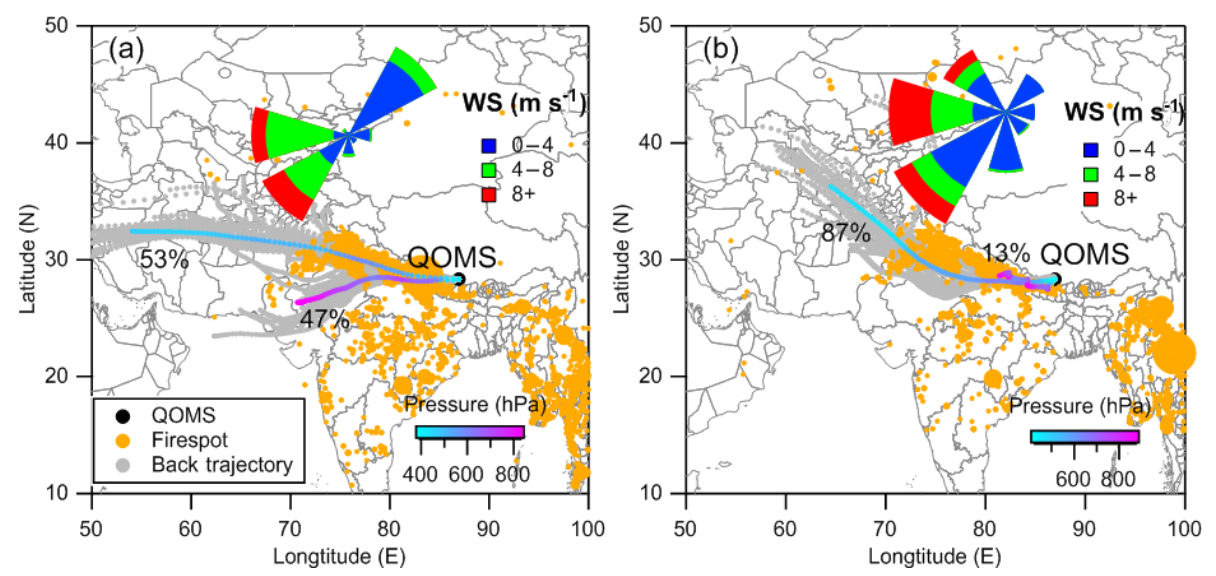

Figure 2. The air mass back trajectory analysis using the HYSPLIT model (Draxler and Hess, 1998) during (a) P1 and (b) P2. The air mass trajectories were recovered back to 72 at a $1 \mathrm{~h}$ interval from the sampling site (QOMS) at $1000 \mathrm{~m}$ above ground level using a $1^{\circ}$ resolution Global Data Assimilation System (GDAS) dataset (https://ready.arl.noaa.gov/gdas1.php; last access: 10 September 2017). The cluster analysis for these trajectories was completed based on the directions of the trajectories (angle distance) and colored according to air pressure (vertical profile). The firespot observed from MODIS (https://firms.modaps.eosdis.nasa.gov; last access: 10 September 2017) and the average wind rose plot colored by wind speed (WS) for during each filter sampling period are also shown. The firespot is sized by fire radiative power.

shown in Fig. 1. The mass concentrations of $\mathrm{PM}_{1}$ were 9.2 and $10.6 \mu \mathrm{g} \mathrm{m}^{-3}$, respectively, which were at the high range of all filters $\left(1.3-10.6 \mu \mathrm{g} \mathrm{m}^{-3}\right)$ because of a continuous longrange transport event at the QOMS (X. Zhang et al., 2018). Due to our sample processing error, the mass concentration of filter measured gravimetrically could not be used, and thus the fractions of $\mathrm{PM}_{1}$ to $\mathrm{PM}_{2.5}$ are not available. However, most of WSOM in $\mathrm{PM}_{2.5}$ is in the accumulation size mode (less than $1 \mu \mathrm{m}$ ) which could be detected by the HRToF-AMS (Zhang et al., 2005). The chemical composition of $\mathrm{PM}_{1}$ during $\mathrm{P} 1$ and $\mathrm{P} 2$ was all dominated by $\mathrm{OA}(55 \%$ and $57 \%$ ), followed by BC ( $26 \%$ and $22 \%)$, sulfate $(7 \%$ and $8 \%$ ), nitrate (5\% and $6 \%$ ), and ammonium (5\% and $6 \%$ ). The OA was comprised of biomass-burning-emitted OA (BBOA), nitrogen-containing OA (NOA), and more oxidized oxygenated OA (MO-OOA) decomposed using positive matrix factorization (PMF) analysis (Fig. 1). Details on PMF analysis can be found in X. Zhang et al. (2018). The mass contribution of BBOA was higher during $\mathrm{P} 2$ than $\mathrm{P} 1$ ( $32 \%$ vs. $22 \%$ ), whereas the contribution of MO-OOA was higher during P1 (24\% vs. $16 \%$ ). The mass spectra of OA for these two filter periods were closely similar to a Poisson correlation efficiency $(r)$ of 0.9 . The elemental ratios of oxygen $(\mathrm{O})$ to carbon $(\mathrm{C})$ of OA were 1.04 and 0.97 for P1 and $\mathrm{P} 2$ periods (Improved Ambient method; Canagaratna et al., 2015), respectively, and the ratios of hydrogen (H) to $\mathrm{C}$ were 1.26 and 1.32 accordingly. These suggest that the OA during $\mathrm{P} 2$ was relatively less oxidized than that during P1 ( $t$ test, $p<0.05)$. The six category ions $\left(\mathrm{C}_{x} \mathrm{H}_{y}^{+}, \mathrm{C}_{x} \mathrm{H}_{y} \mathrm{O}_{2}^{+}\right.$, $\mathrm{C}_{x} \mathrm{H}_{y} \mathrm{O}_{1}^{+}, \mathrm{C}_{x} \mathrm{H}_{y} \mathrm{~N}^{+}, \mathrm{C}_{x} \mathrm{H}_{y} \mathrm{O}_{z} \mathrm{~N}^{+}$, and $\mathrm{HO}^{+}$) detected by the HR-ToF-AMS for these two filter periods were all dominated by $\mathrm{C}_{x} \mathrm{H}_{y} \mathrm{O}_{2}^{+}$, following by $\mathrm{C}_{x} \mathrm{H}_{y}^{+}, \mathrm{C}_{x} \mathrm{H}_{y} \mathrm{O}_{1}^{+}, \mathrm{C}_{x} \mathrm{H}_{y} \mathrm{~N}^{+}$,
$\mathrm{C}_{x} \mathrm{H}_{y} \mathrm{O}_{z} \mathrm{~N}^{+}$, and $\mathrm{HO}^{+}$. The air mass trajectory analyses using the hybrid single particle Lagrangian integrated trajectory (HYSPLIT) model for $\mathrm{P} 1$ and $\mathrm{P} 2$ periods show air mass mainly originated from west and southwest of the QOMS across north and northwest India where there were many firespots during these two periods (Fig. 2). The air mass during P2 was partly (13\%) transported with a low wind speed and across a short distance (less than $100 \mathrm{~km}$ ), and could contain some fresh OA as illustrated by the higher fraction of BBOA.

\subsection{The chemical characteristics of WSOM from ESI-FTICR MS}

A total of 4295 and 4770 molecular formulas were identified by ESI-FTICT MS over the mass range of 100-700 Da for P1 and $\mathrm{P} 2$, respectively. The identified molecular formulas were grouped into two subgroups based on their elemental composition, i.e., $\mathrm{CHO}$ and $\mathrm{CHON}$, all of which had equally important contributions $(45 \%-55 \%)$ in number (Fig. 3). Note that individual species in the ESI-FTICR MS mass spectra could have many different isomeric structures, in which case the percentages only reflect the number of unique molecular formulas in each category. The mass spectra of these two samples were highly similar in the distributions of molecular formulas (Fig. 3). The average weighted element ratios of $\mathrm{P} 1$ and $\mathrm{P} 2$ were 0.43 vs. 0.39 for $\mathrm{O} / \mathrm{C}_{\mathrm{w}}, 1.36$ vs. 1.31 for $\mathrm{H} / \mathrm{C}_{\mathrm{w}}$, and 1.72 vs. 1.68 for $\mathrm{OM} / \mathrm{OC}_{\mathrm{w}}$ (Table 1), suggesting a relatively higher oxidation and saturation degree for P1 than P2. These trends are consistent with the results of the HR-ToF-AMS, although the elemental ratios are different between them, which is due to the difference in the detection 
Table 1. Chemical characterization of all molecular assignments detected in WSOM for P1, P2, and common ions. Relative intensity weighted ("w") for each data subset $(\mathrm{O} / \mathrm{C}, \mathrm{H} / \mathrm{C}, \mathrm{OM} / \mathrm{OC}, \mathrm{DBE}$, and $\mathrm{DBE} / \mathrm{C})$ is given.

\begin{tabular}{|c|c|c|c|c|}
\hline & & All & $\mathrm{CHO}$ & $\mathrm{CHON}$ \\
\hline \multirow{8}{*}{$\mathrm{P} 1$} & $\mathrm{O} / \mathrm{C}_{\mathrm{w}}$ & 0.43 & 0.44 & 0.42 \\
\hline & $\mathrm{H} / \mathrm{C}_{\mathrm{W}}$ & 1.36 & 1.37 & 1.34 \\
\hline & $\mathrm{OM} / \mathrm{OC}_{\mathrm{w}}$ & 1.72 & 1.70 & 1.76 \\
\hline & $\mathrm{DBE}_{\mathrm{W}}$ & 7.12 & 6.74 & 7.79 \\
\hline & $\mathrm{DBE} / \mathrm{C}_{\mathrm{W}}$ & 0.39 & 0.37 & 0.43 \\
\hline & Percentage $(\%)$ of aliphatic $\left(\mathrm{AI}_{\bmod }=0\right)$ & 18.4 & 9.4 & 9.0 \\
\hline & Olefinic $\left(0.5>\mathrm{AI}_{\mathrm{mod}}>0\right)$ & 73.9 & 39.7 & 34.2 \\
\hline & Aromatic $\left(\mathrm{AI}_{\mathrm{mod}} \geq 0.5\right)$ & 7.7 & 4.1 & 3.5 \\
\hline \multirow{8}{*}{$\mathrm{P} 2$} & $\mathrm{O} / \mathrm{C}_{\mathrm{w}}$ & 0.39 & 0.39 & 0.39 \\
\hline & $\mathrm{H} / \mathrm{C}_{\mathrm{W}}$ & 1.31 & 1.32 & 1.31 \\
\hline & $\mathrm{OM} / \mathrm{OC}_{\mathrm{W}}$ & 1.68 & 1.63 & 1.73 \\
\hline & $\mathrm{DBE}_{\mathrm{W}}$ & 7.87 & 7.38 & 8.32 \\
\hline & $\mathrm{DBE} / \mathrm{C}_{\mathrm{W}}$ & 0.42 & 0.40 & 0.44 \\
\hline & Percentage $(\%)$ of aliphatic $\left(\mathrm{AI}_{\bmod }=0\right)$ & 14.7 & 6.0 & 8.7 \\
\hline & Olefinic $\left(0.5>\mathrm{AI}_{\text {mod }}>0\right)$ & 75.0 & 34.3 & 40.7 \\
\hline & Aromatic $\left(\mathrm{AI}_{\mathrm{mod}} \geq 0.5\right)$ & 10.3 & 4.9 & 5.4 \\
\hline \multirow{8}{*}{ Common ions } & $\mathrm{O} / \mathrm{C}_{\mathrm{w}}$ & 0.42 & 0.43 & 0.42 \\
\hline & $\mathrm{H} / \mathrm{C}_{\mathrm{W}}$ & 1.35 & 1.36 & 1.33 \\
\hline & $\mathrm{OM} / \mathrm{OC}_{\mathrm{w}}$ & 1.72 & 1.69 & 1.76 \\
\hline & $\mathrm{DBE}_{\mathrm{W}}$ & 7.18 & 6.75 & 7.79 \\
\hline & $\mathrm{DBE} / \mathrm{C}_{\mathrm{W}}$ & 0.40 & 0.38 & 0.43 \\
\hline & Percentage $(\%)$ of aliphatic $\left(\mathrm{AI}_{\bmod }=0\right)$ & 15.6 & 6.7 & 8.9 \\
\hline & Olefinic $\left(0.5>\mathrm{AI}_{\text {mod }}>0\right)$ & 76.5 & 39.7 & 36.8 \\
\hline & Aromatic $\left(\mathrm{AI}_{\bmod } \geq 0.5\right)$ & 7.8 & 4.3 & 3.6 \\
\hline
\end{tabular}

Table 2. Chemical characterization of the molecular assignments detected in aerosol samples from selected studies (adapted and modified from Table 3 in Dzepina et al., 2015). Note that all values are presented as arithmetic means, which are given for convenience of comparison. The data for our study are the arithmetic means for P1 and P2.

\begin{tabular}{lllrrrrrr}
\hline Sample type & Measurement site & Instrument & O/C & H/C & OM/OC & DBE & DBE/C & Reference \\
\hline Aerosol & Remote & ESI(+)-FTICR MS & $0.39-0.42$ & $1.30-1.34$ & $1.68-1.72$ & $7.71-8.38$ & $0.41-0.42$ & This study \\
Aerosol & Free troposphere & ESI(-)-FTICR MS & $0.42-0.46$ & $1.17-1.28$ & $1.67-1.73$ & $9.4-10.7$ & $0.42-0.47$ & Dzepina et al. (2015) \\
Aerosol & Remote & ESI(-)-FTICR MS & $0.53 \pm 0.2$ & $1.48 \pm 0.3$ & $1.91 \pm 0.3$ & $6.18 \pm 3.0$ & NA & Mazzoleni et al. (2012) \\
Aerosol & Rural & ESI(-)-FTICR MS & $0.28-0.32$ & $1.37-1.46$ & $1.54-1.60$ & $6.30-7.45$ & $0.33-0.38$ & Wozniak et al. (2008) \\
Aerosol & Suburban & ESI(-)-FTICR MS & 0.46 & 1.34 & 1.85 & 5.3 & 0.45 & Lin et al. (2012) \\
Aerosol & Urban & ESI(+)-FTICR MS & 0.31 & 1.34 & NA & 8.68 & 0.41 & Choi et al. (2017) \\
Aerosol & Marin boundary layer & ESI(-)-FTICR MS & 0.35 & 1.59 & 1.67 & 4.37 & 0.28 & Schmitt-Kopplin et al. (2012) \\
Aerosol & Marine boundary layer & ESI(-)-FTICR MS & $0.36-0.42$ & $1.49-1.56$ & $1.70-1.74$ & $5.88-6.76$ & $0.28-0.32$ & Wozniak et al. (2014) \\
Cloud water & Remote & ESI(-)-FTICR MS & $0.61-0.62$ & 1.46 & $2.06-2.08$ & $6.29-6.30$ & 0.38 & Zhao et al. (2013) \\
Cloud water & Rural & ESI(-)-FTICR MS & 0.51 & 1.47 & NA & 6.03 & NA & Cook et al. (2017) \\
Fog water & Rural & ESI(-)-FTICR MS & 0.43 & 1.39 & 1.77 & 5.6 & 0.40 & Mazzoleni et al. (2010) \\
\hline
\end{tabular}

NA: not available

range of $m / z$ and the ionization efficiency of different mass spectrometry (ESI vs. electron impact) (Yu et al., 2016). The elemental ratios of WSOM from ESI-FTICR MS in our study are similar to those results observed in aerosol samples in remote sites using ESI-FTICR MS (e.g., 0.35-0.53 for O/C) (Table 2). The $\mathrm{O} / \mathrm{C}$ and $\mathrm{H} / \mathrm{C}$ in Van Krevelen diagrams (Wu et al., 2004) for these two filters and the subgroup molecular formulas show similar distributions, and are all concentrated in ranges of $1.2-1.8$ for $\mathrm{H} / \mathrm{C}$ and $0.3-0.7$ for $\mathrm{O} / \mathrm{C}$ (Fig. 3), suggesting their similar aerosol sources and atmospheric processes. The similar distributions for these two filters are also observed in plots of KMD vs. KM and DBE vs. C (Fig. 3).

Structural information for the assigned molecular formulas is inferred from the $\mathrm{DBE}_{\mathrm{w}}$ value which was higher for P2 than for P1 (7.87 vs. 7.12) (Table 1). Compared with other studies, the $\mathrm{DBE}_{\mathrm{w}}$ values in our filter are relatively close to the results from biomass burning aerosol and aerosol samples from remote sites (Table 2) (Dzepina et al., 2015). The $\mathrm{DBE}_{\mathrm{w}}$ 

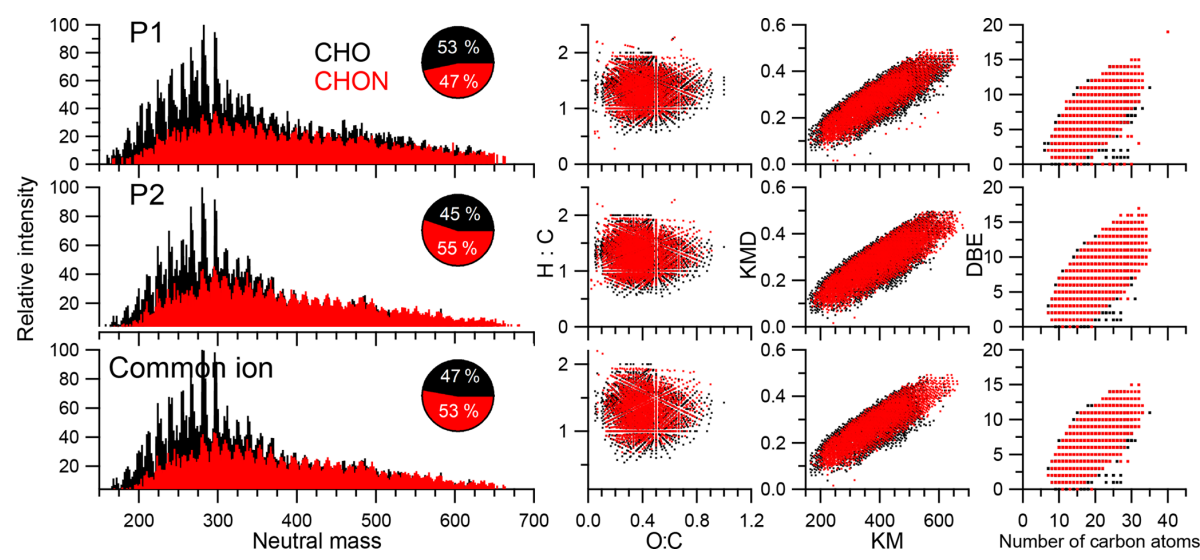

Figure 3. The combination plot for all molecular formulas of $\mathrm{P} 1, \mathrm{P} 2$, and common ions including the high-resolution mass spectrum, the Van Krevelen diagram, Kendrick mass defects (KMDs) vs. Kendrick mass (KM), and double bond equivalents (DBEs) vs. number of carbon atoms.

values for each molecular subgroup were higher for $\mathrm{CHON}$ than for $\mathrm{CHO}$ (Table 1), especially for P2 (8.32 vs. 7.38), suggesting more rings and double bonds in $\mathrm{CHON}$ molecular formulas. The $\mathrm{AI}_{\text {mod }}$, reflecting the minimum number of carbon-carbon double bonds and rings (Koch and Dittmar, 2006), was correspondingly higher in $\mathrm{P} 2$ as illustrated by its higher contribution of olefinic $(75.0 \%$ vs. $73.9 \%$ for P2 and $\mathrm{P} 1)$ and aromatic compounds (10.3\% vs. $7.7 \%$ for P2 and $\mathrm{P} 1)$ (Table 1). For aromatic compounds $\left(\mathrm{AI}_{\bmod } \geq 0.5\right)$ in $\mathrm{P} 2,52 \%$ of them were CHON formulas ( $45 \%$ for P1). Higher DBE and $\mathrm{AI}_{\text {mod }}$ values in CHON compounds suggest more unsaturated compounds in them which could contain a certain number of chromophores. The distribution of DBE vs. the carbon number of two filters showed a systematic increase in a concentrated region and a high similarity with each other. This similarity further suggests the consistent source and chemical processes for the aerosol of these two filters.

There were 3955 common molecular formulas between these two filters with the number contribution of $\mathrm{CHO}$ of $50.7 \%$ and $\mathrm{CHON}$ of $49.3 \%$. These common molecular formulas accounted for $92.1 \%$ (P1) and $82.9 \%$ (P2) of two filters, respectively. There were 340 unique molecular formulas in $\mathrm{P} 1$, with $73 \%$ being $\mathrm{CHO}$ compounds, whereas there were 815 unique molecular formulas in $\mathrm{P} 2$, with $65.3 \%$ being CHON compounds. For more confidence in molecule assignment, we focus on the common molecular formulas detected in these two samples in the section below. Note that the mass spectrum of common ions was calculated from the average RI from two mass spectra and normalized to the highest peak.

\subsection{The potential sources and formation processes}

\subsubsection{CHO compounds}

CHO compounds have been frequently detected in ambient aerosol samples (Altieri et al., 2009b; Mazzoleni et al., 2010; Lin et al., 2012; Fleming et al., 2018), which could comprise high molecular weight humic-like substances (HULIS) or oligomers, and in primary emission or secondary formation of different aerosol sources (Mazzoleni et al., 2012; Wozniak et al., 2014; Lin et al., 2016; Cook et al., 2017). In our samples, the weighted molecular weight of $\mathrm{CHO}$ compounds was 361.9 , with an average $C$ atom of $19.3 \pm 5.3$ per molecule; the most abundant $\mathrm{O}$ atoms were located in the range $5-10$, with an average value of $7.8 \pm 2.9$ per molecule (Fig. 4a and b). The oxygen distribution is also evidenced by the longest homologous series in the second-order mass defect analysis $\left(\mathrm{CH}_{2}-\mathrm{H}_{2}\right)$, which were all $\mathrm{O}_{5}-\mathrm{O}_{10}$ compounds (Fig. 4d). The DBE of CHO increased with carbon number, with a $\mathrm{DBE}_{\mathrm{w}}$ value of 6.75 (Fig. 3); the carbon-normalized DBE (DBE/C) was $0.39 \pm 0.14$. These two values were close to the results from biomass burning aerosol samples in other studies and are in a high range of published data (Table 2) (Lin et al., 2012; Mazzoleni et al., 2012), suggesting relatively high aromaticity in our samples. The carbon oxidation state $\left(\mathrm{OS}_{\mathrm{C}}\right)$ values (Kroll et al., 2011), a useful metric for the degree of oxidation of organic species in the atmosphere, exhibited between -1 and 0 for high number density formulas, with 25 or fewer carbon atoms, suggesting that they are semi- and low-volatile organic compounds, corresponding to "fresh" (BBOA) and "aged" (LV-OOA) SOA by multistep oxidation reactions (Fig. 4c).

There are several possible sources and chemical formation pathways for high-oxygen-containing $\mathrm{CHO}$ compounds. Ozonolysis of $\alpha$-pinene has been found to form highly oxygenated molecules with some important products such as $\mathrm{C}_{17} \mathrm{H}_{26} \mathrm{O}_{8}\left(m / z\right.$ 358) and $\mathrm{C}_{19} \mathrm{H}_{28} \mathrm{O}_{7}(\mathrm{~m} / z$ 368), which 

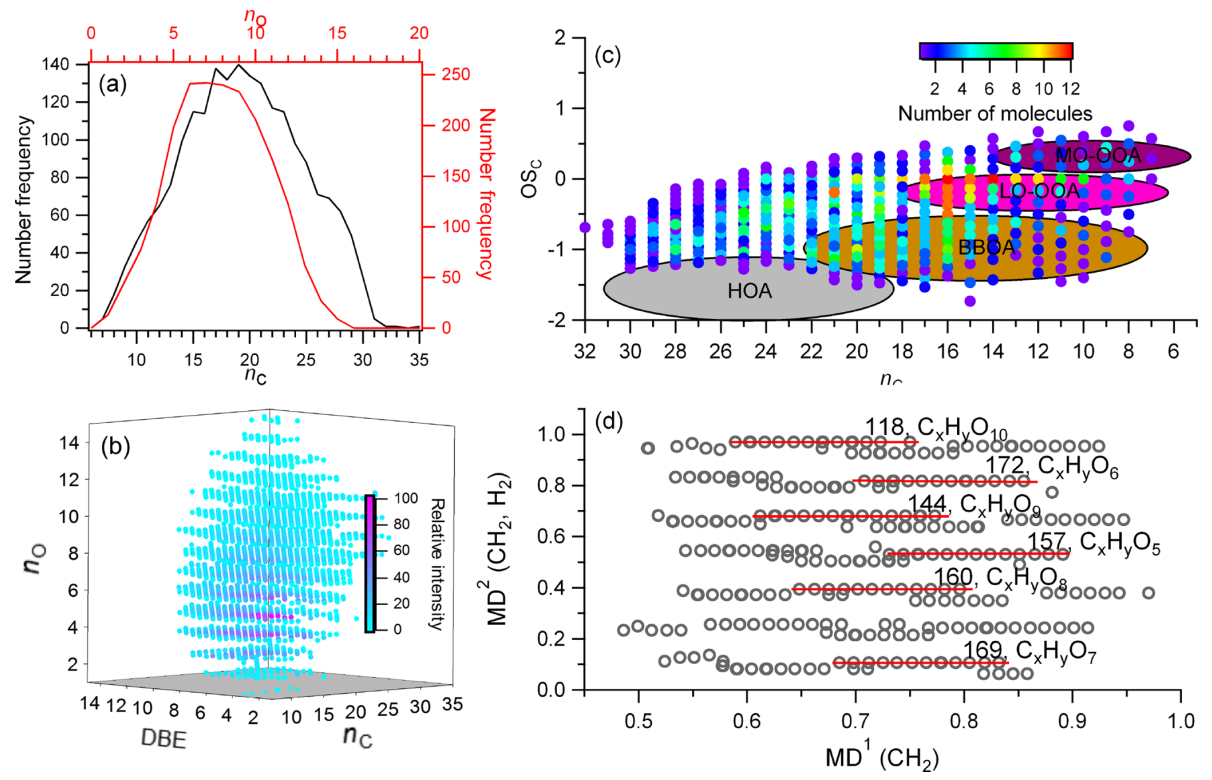

Figure 4. The molecular information for common CHO compounds. (a) The number frequency distribution of carbon $\left(n_{\mathrm{c}}\right)$ and oxygen $\left(n_{\mathrm{o}}\right)$. (b) The 3-D plot for $n_{\mathrm{o}}, n_{\mathrm{c}}$, and double bond equivalents (DBEs) colored by their relative intensity. (c) Scatter plot of carbon-based oxidation state $(\mathrm{OSc})$ vs. $n_{\mathrm{c}}$ colored by the distribution of number of molecules. (d) The second-order mass defect analysis $\left(\mathrm{MD}^{2}\left(\mathrm{CH}_{2}, \mathrm{H}_{2}\right)\right.$ vs. $\mathrm{MD}^{1}$ $\left(\mathrm{CH}_{2}\right)$ ) using the base of $\mathrm{CH}_{2}$ and $\mathrm{H}_{2}$. The longest homologous series are marked with the group number and formula type.

are possible esterification products of $c i s$-pinic $\left(\mathrm{C}_{9} \mathrm{H}_{14} \mathrm{O}_{4}\right.$; $m / z$ 186) and diaterpenylic acid $\left(\mathrm{C}_{8} \mathrm{H}_{14} \mathrm{O}_{5} ; m / z\right.$ 190) (Kristensen et al., 2013). The first three formulas were all found in our common $\mathrm{CHO}$ molecules with high relative abundance (Table 3). The appearance of these formulas together with high relative abundance gave us more confidence in the products of ozonolysis of $\alpha$-pinene. Ozone concentration in the Himalayas during the pre-monsoon period was the highest based on online measurement at the Nepal Climate Observatory at Pyramid (NCO-P) during 2006-2008 $(61 \pm 9$ ppbv) (Cristofanelli et al., 2010). Biogenic volatile organic compounds could be transported from the low elevation regions in subtropical India and biogenic secondary organic aerosol has been found to be an important source in the Himalayas (Stone et al., 2012). A number of other previously reported monoterpene oxidation product formulas were also observed in our study (Table 3) (Claeys et al., 2007; Kleindienst et al., 2007; H. Zhang et al., 2018). In addition, some biomass burning aerosol markers were also found in CHO compounds. Sun et al. (2010) and Yu et al. $(2014,2016)$ observed that aqueous-phase oxidation of lignin produces phenol $\left(\mathrm{C}_{6} \mathrm{H}_{6} \mathrm{O}\right)$, guaiacol $\left(\mathrm{C}_{7} \mathrm{H}_{8} \mathrm{O}_{2}\right)$, and syringol $\left(\mathrm{C}_{8} \mathrm{H}_{10} \mathrm{O}_{3}\right)$, yielding a substantial fraction of dimers and higher oligomers, with key dimer markers identified as $\mathrm{C}_{16} \mathrm{H}_{18} \mathrm{O}_{6}$ and $\mathrm{C}_{14} \mathrm{H}_{14} \mathrm{O}_{4}$. The dimer markers $\mathrm{C}_{16} \mathrm{H}_{18} \mathrm{O}_{6}$ and $\mathrm{C}_{14} \mathrm{H}_{14} \mathrm{O}_{4}$ were also present in our sample with high RI $(5.5 \%$ and $27.5 \%)$. The high relative intensity of these compounds indicates that fog and cloud processing of phenolic species (biomass burning aerosol) could be an important mechanism for the production of low-volatility SOA in the
Himalayas. Compounds observed in biomass burning emission (cow dung and brush wood) during residential cooking in Nepal were also found in our samples (Fleming et al., 2018)

\subsubsection{CHON compounds}

The frequency distribution for $n_{\mathrm{o}}$ and $n_{\mathrm{c}}$ in CHON formulas was shown in Fig. 5a, which show peaks between 6 and 10 and 15 and 20, respectively. The DBE of CHON formulas ranged from 4 to 10 , with $\mathrm{DBE}_{\mathrm{w}}$ being 7.79 (Fig. $5 \mathrm{~b}$ and Table 1). In the CHON class, compounds contained one or two nitrogen $(1 \mathrm{~N}$ or $2 \mathrm{~N})$ atoms, with $1 \mathrm{~N}$ compounds accounting for $70.5 \%$ and $2 \mathrm{~N}$ for $29.5 \%$, respectively. Most $(93.6 \%)$ $1 \mathrm{~N}$ compounds contained more than 3 oxygen atoms and up to 13 oxygen atoms, whereas about $62.5 \%$ of $2 \mathrm{~N} \mathrm{com-}$ pounds contained more than 6 oxygen atoms (Fig. 6a). The average $\mathrm{O}$ atoms contained in each molecular formula were therefore higher for $1 \mathrm{~N}$ compounds than $2 \mathrm{~N}$ compounds $(8.1 \pm 2.9$ vs. $6.3 \pm 2.3)$. The ratios of $\mathrm{O} / \mathrm{C}_{\mathrm{w}}$ and $\mathrm{OS}_{\mathrm{C}_{\mathrm{w}}}$ for $1 \mathrm{~N}$ compounds were accordingly higher than those for $2 \mathrm{~N}$ compounds ( 0.42 vs. 0.37 for $\mathrm{O} / \mathrm{C}_{\mathrm{w}}$ and -0.48 vs. -0.54 for ${ } S_{C_{w}}$, respectively), suggesting a higher oxidation state for $1 \mathrm{~N}$ compounds (Fig. 5c). In contrast, the $\mathrm{DBE}_{\mathrm{w}}$ and $\mathrm{AI}_{\text {mod }}$ values for $2 \mathrm{~N}$ compounds were higher than for $1 \mathrm{~N}$ compounds (Table 1 ). The higher $\mathrm{H} / \mathrm{C}_{\mathrm{w}}$ for $2 \mathrm{~N}$ compounds (Fig. 5d) suggests that $2 \mathrm{~N}$ compounds could contain many aromatic N-heterocyclic compounds. For $1 \mathrm{~N}$ compounds, longer and higher relative intensity $\mathrm{CH}_{2}$ homologous series compounds were found based on the Kendrick mass defect 
Table 3. List of identified BVOC products and biomass-burning-emission-related compounds in this study.

\begin{tabular}{|c|c|c|c|c|}
\hline Mass $(m / z)$ & Molecular formula & Relative intensity & Compound type & References \\
\hline 358.1622 & $\mathrm{C}_{17} \mathrm{H}_{26} \mathrm{O}_{8}$ & $33.1 \%$ & \multirow{3}{*}{$\alpha$-Pinene products } & \multirow{3}{*}{ Kristensen et al., 2013} \\
\hline 368.1829 & $\mathrm{C}_{19} \mathrm{H}_{28} \mathrm{O}_{7}$ & $11.5 \%$ & & \\
\hline 186.0887 & $\mathrm{C}_{9} \mathrm{H}_{14} \mathrm{O}_{4}$ & $26.0 \%$ & & \\
\hline 168.0417 & $\mathrm{C}_{8} \mathrm{H}_{8} \mathrm{O}_{4}$ & $4.75 \%$ & \multirow{3}{*}{ Monoterpene products } & \multirow{3}{*}{$\begin{array}{l}\text { Claeys et al. (2007), Kleindi- } \\
\text { enst et al. (2007), H. Zhang et } \\
\text { al. (2018) }\end{array}$} \\
\hline 182.0574 & $\mathrm{C}_{9} \mathrm{H}_{10} \mathrm{O}_{4}$ & $8.12 \%$ & & \\
\hline 198.0523 & $\mathrm{C}_{9} \mathrm{H}_{10} \mathrm{O}_{5}$ & $11.6 \%$ & & \\
\hline 231.0737 & $\mathrm{C}_{9} \mathrm{H}_{13} \mathrm{NO}_{6}$ & $12.7 \%$ & \multirow{9}{*}{ BVOC oxidant products } & \multirow{9}{*}{$\begin{array}{l}\text { Lee et al. (2016), H. Zhang e } \\
\text { al. (2018) }\end{array}$} \\
\hline 233.0894 & $\mathrm{C}_{9} \mathrm{H}_{15} \mathrm{NO}_{6}$ & $14.0 \%$ & & \\
\hline 215.1152 & $\mathrm{C}_{10} \mathrm{H}_{17} \mathrm{NO}_{4}$ & $10.6 \%$ & & \\
\hline 229.0945 & $\mathrm{C}_{10} \mathrm{H}_{15} \mathrm{NO}_{5}$ & $16.5 \%$ & & \\
\hline 231.1101 & $\mathrm{C}_{10} \mathrm{H}_{17} \mathrm{NO}_{5}$ & $16.8 \%$ & & \\
\hline 233.1257 & $\mathrm{C}_{10} \mathrm{H}_{19} \mathrm{NO}_{5}$ & $9.5 \%$ & & \\
\hline 245.0894 & $\mathrm{C}_{10} \mathrm{H}_{15} \mathrm{NO}_{6}$ & $26.4 \%$ & & \\
\hline 247.1050 & $\mathrm{C}_{10} \mathrm{H}_{17} \mathrm{NO}_{6}$ & $16.5 \%$ & & \\
\hline 249.1207 & $\mathrm{C}_{10} \mathrm{H}_{19} \mathrm{NO}_{6}$ & $9.6 \%$ & & \\
\hline 306.1099 & $\mathrm{C}_{16} \mathrm{H}_{18} \mathrm{O}_{6}$ & $5.5 \%$ & \multirow{2}{*}{$\begin{array}{l}\text { Aqueous-phase oxidation of } \\
\text { biomass burning aerosol }\end{array}$} & \multirow{2}{*}{$\begin{array}{l}\text { Yu et al. (2014, 2016), } \\
\text { Sun et al. }(2010)\end{array}$} \\
\hline 246.0886 & $\mathrm{C}_{14} \mathrm{H}_{14} \mathrm{O}_{4}$ & $27.5 \%$ & & \\
\hline 166.0624 & $\mathrm{C}_{9} \mathrm{H}_{10} \mathrm{O}_{3}$ & $4.9 \%$ & \multirow{10}{*}{$\begin{array}{l}\text { Cow dung and brush } \\
\text { wood burning }\end{array}$} & \multirow{10}{*}{ Fleming et al., 2018} \\
\hline 178.0624 & $\mathrm{C}_{10} \mathrm{H}_{10} \mathrm{O}_{3}$ & $5.7 \%$ & & \\
\hline 190.0624 & $\mathrm{C}_{11} \mathrm{H}_{10} \mathrm{O}_{3}$ & $7.7 \%$ & & \\
\hline 192.0781 & $\mathrm{C}_{11} \mathrm{H}_{12} \mathrm{O}_{3}$ & $7.0 \%$ & & \\
\hline 188.0832 & $\mathrm{C}_{12} \mathrm{H}_{12} \mathrm{O}_{2}$ & $4.3 \%$ & & \\
\hline 216.0781 & $\mathrm{C}_{13} \mathrm{H}_{12} \mathrm{O}_{3}$ & $12.5 \%$ & & \\
\hline 218.0937 & $\mathrm{C}_{13} \mathrm{H}_{14} \mathrm{O}_{3}$ & $16.7 \%$ & & \\
\hline 198.0866 & $\mathrm{C}_{13} \mathrm{H}_{14} \mathrm{O}_{4}$ & $30.5 \%$ & & \\
\hline 248.1043 & $\mathrm{C}_{14} \mathrm{H}_{16} \mathrm{O}_{4}$ & $32.2 \%$ & & \\
\hline 232.1094 & $\mathrm{C}_{14} \mathrm{H}_{16} \mathrm{O}_{3}$ & $21.6 \%$ & & \\
\hline 338.0745 & $\mathrm{C}_{14} \mathrm{H}_{14} \mathrm{~N}_{2} \mathrm{O}_{8}$ & $5.7 \%$ & \multirow{7}{*}{ Biomass burning aerosol } & \multirow{7}{*}{ Song et al. (2018) } \\
\hline 341.1105 & $\mathrm{C}_{15} \mathrm{H}_{19} \mathrm{~N}_{1} \mathrm{O}_{8}$ & $27.2 \%$ & & \\
\hline 355.1261 & $\mathrm{C}_{16} \mathrm{H}_{21} \mathrm{~N}_{1} \mathrm{O}_{8}$ & $29.4 \%$ & & \\
\hline 369.1418 & $\mathrm{C}_{17} \mathrm{H}_{23} \mathrm{~N}_{1} \mathrm{O}_{8}$ & $24.0 \%$ & & \\
\hline 243.0890 & $\mathrm{C}_{14} \mathrm{H}_{13} \mathrm{~N}_{1} \mathrm{O}_{3}$ & $9.3 \%$ & & \\
\hline 257.1046 & $\mathrm{C}_{15} \mathrm{H}_{15} \mathrm{~N}_{1} \mathrm{O}_{3}$ & $9.5 \%$ & & \\
\hline 235.1203 & $\mathrm{C}_{13} \mathrm{H}_{17} \mathrm{~N}_{1} \mathrm{O}_{3}$ & $17.0 \%$ & & \\
\hline
\end{tabular}

plot (Fig. 6b); 1073 of the 1373 detected $1 \mathrm{~N}$ compounds can be grouped into 145 homologous groups. The abundant long $\mathrm{CH}_{2}$ homologous series in $1 \mathrm{~N}$ compounds contained 7-10 O atoms, while that in $2 \mathrm{~N}$ compounds contained 5-8 $\mathrm{O}$ atoms (Fig. 6).

Many CHON compounds could be identified in ESI+ mode, such as reduced $\mathrm{N}$ functional compounds and nitroaromatic compounds (Altieri et al., 2009a; Laskin et al., 2009; Lin et al., 2012; O'Brien et al., 2013; Wang et al., 2017). Laskin et al. (2009) identified the amount of N-heterocyclic alkaloid compounds from types of fresh biomass burning aerosol. Lin et al. (2012) and Wang et al. (2017) also identified many CHON compounds in fresh and aged biomass burning aerosol. Oxygenated organic nitrogen compounds in ambient aerosol (Dzepina et al., 2015), rainwater (Altieri et al., 2009a), and fog water (Mazzoleni et al., 2010) from biomass-burning-emission-influenced regions were also observed. Lin et al. (2017) found aged biomass burning aerosol in the present urban oxidants (such as $\mathrm{NO}_{x}$ ) could result in a higher fraction of CHON compounds compared to the fresh biomass burning aerosol. Considering the high influence of biomass burning emission in the Himalayas (X. Zhang et al., 2018), the CHON compounds in our study were probably related to biomass burning emissions. Recent studies have proven that burning of mixed biomass fuels in Nepal could emit amounts of nitrogen species such as $\mathrm{NH}_{3}, \mathrm{NO}_{x}, \mathrm{HCN}$, benzene, and organics, and the emission factors for these species are higher than for wood (Stockwell et al., 2016; Jayarathne et al., 2018). In addition, it is likely that smoldering burning of bio-fuels in high elevation areas is also re- 

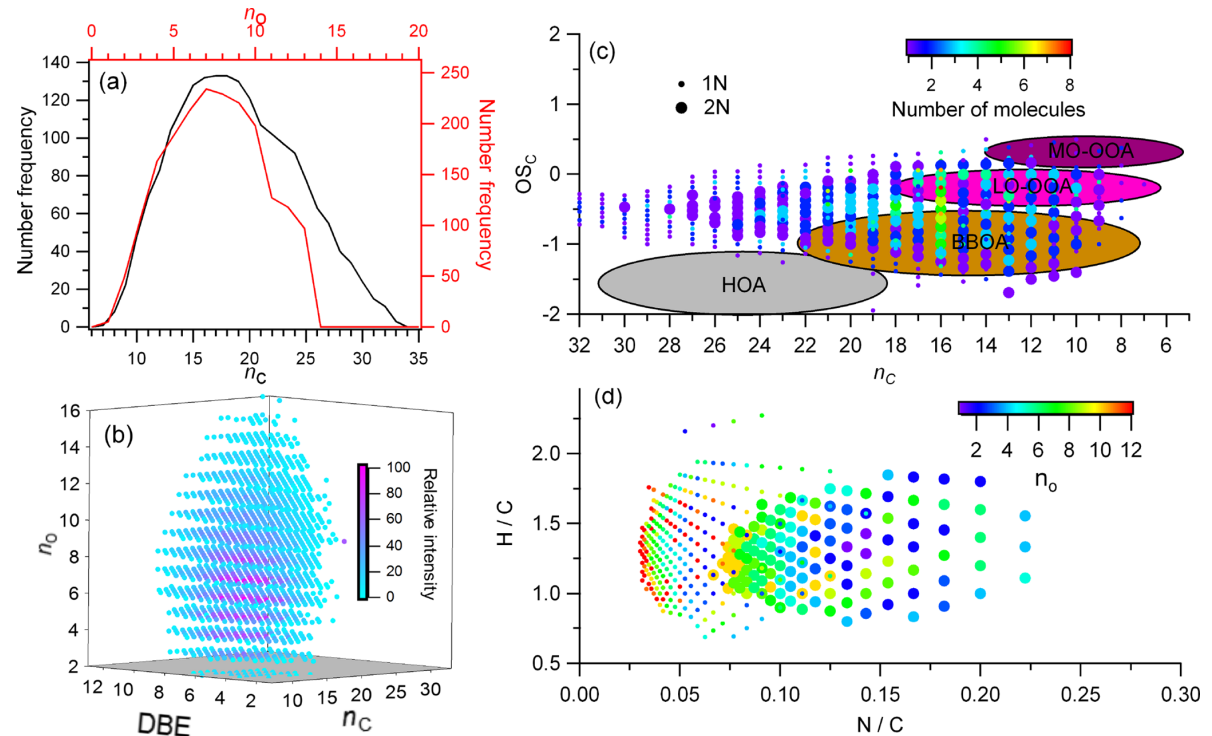

Figure 5. The molecular information for common CHON compounds. (a) The number frequency distribution of carbon $\left(n_{\mathrm{c}}\right)$ and oxygen $\left(n_{\mathrm{O}}\right)$. (b) The 3-D plot for $n_{\mathrm{o}}, n_{\mathrm{c}}$, and double bond equivalents (DBEs) colored by their relative intensity. (c) Scatter plot of carbon-based oxidation state (OSc) vs. $n_{\mathrm{c}}$ colored by the distribution of number of molecules. (d) The Van Krevelen diagram by $\mathrm{H} / \mathrm{C}$ vs. N/C colored by number of oxygen $\left(n_{\mathrm{O}}\right)$. The different sizes of dot marker in $(\mathbf{c})$ and $(\mathbf{d})$ represent the $1 \mathrm{~N}$ and $2 \mathrm{~N}$ compounds.
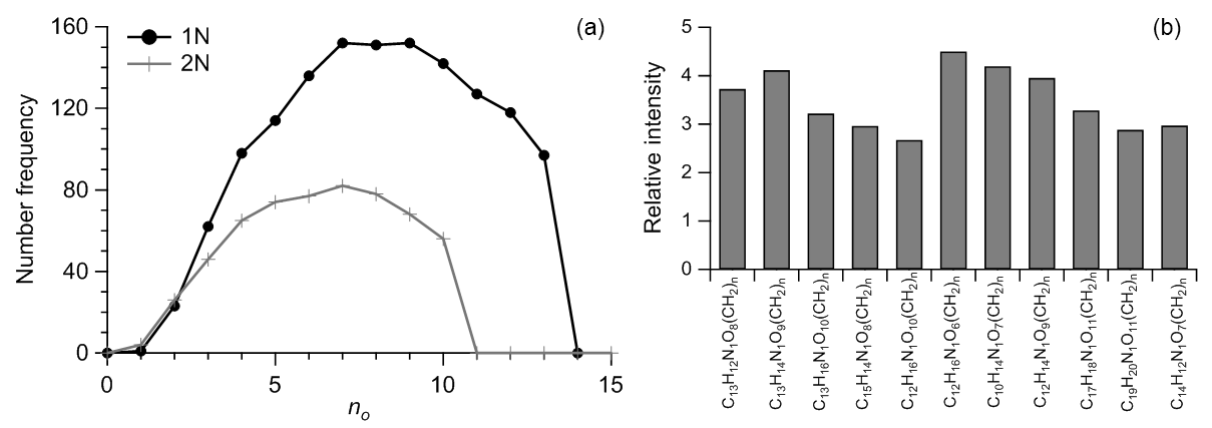

Figure 6. (a) The number frequency distribution of $n_{\mathrm{o}}$ for $1 \mathrm{~N}$ and $2 \mathrm{~N}$ compounds and (b) the longest $10 \mathrm{CH}_{2}$ homologous series compounds in $1 \mathrm{~N}$ compounds.

sponsible for the presence of many nitrogen-containing compounds in BBOA (Chen et al., 2010). Nitroaromatic compounds such as methylnitrocatechols $\left(\mathrm{C}_{7} \mathrm{H}_{7} \mathrm{NO}_{4}\right)$ are introduced to be tracers for biomass burning secondary organic aerosols (Iinuma et al., 2010). Although the $\mathrm{C}_{7} \mathrm{H}_{7} \mathrm{NO}_{4}$ formula is not found in our measurement, $\mathrm{C}_{14} \mathrm{H}_{14} \mathrm{~N}_{2} \mathrm{O}_{8}$ was found in our measurement, which was probably its dimer formula. In addition, the homologous series compounds in which $\mathrm{C}_{7} \mathrm{H}_{7} \mathrm{NO}_{4}$ serves as the core molecule were also found in our samples. Some high relative abundance $\mathrm{CHON}$ molecular formulas identified in a recent paper from biomass burning aerosol were also found in our measurement (Table 3) (Song et al., 2018).

Besides primary emission and/or secondary formation from biomass burning emission, nitrogen-containing OA could also be formed through other chemical processes. For example, biogenic volatile organic compounds (BVOCs) can react with $\mathrm{NO}_{3}$ radicals or $\mathrm{RO}_{2}+\mathrm{NO}$ into organic nitrate (Ng et al., 2017). Although organic nitrate is not favored to be ionized in positive ESI-MS (Wan and Yu, 2006), organic nitrate formed from BVOC could be highly functionalized (Lee et al., 2016) and ionized in positive MS through other alkaline functional groups. Recent studies have shown that BVOCs, including isoprene $\left(\mathrm{C}_{5} \mathrm{H}_{8}\right)$ and monoterpenes $\left(\mathrm{C}_{10} \mathrm{H}_{16}\right)$, dominate the organic nitrate formation in the southeastern United States under the condition of the mixed anthropogenic $\mathrm{NO}_{x}$ and BVOCs (Xu et al., 2014; Lee et al., 2016; H. Zhang et al., 2018). Several molecular formulas formed from monoterpene and $\mathrm{NO}_{3}$ radicals were found in our study (Table 3) (Lee et al., 2016; H. Zhang et al., 2018). 


\section{Implications and limitations}

This study analyzed the WSOM using ESI(+) FTICR MS in fine particulate aerosol from the Himalayas and found that the molecular compositions of WSOM were mainly comprised of two group compounds ( $\mathrm{CHO}$ and $\mathrm{CHON}$ ) with equally important contributions. The two compound groups could be originated from biomass burning emission and BVOC oxidation products because many markers for these two sources were found in these molecular compounds. All our compounds had relatively high DBE values, suggesting a potential high light absorption feature. Due to the relative higher mass concentration and higher contribution of nitrogen-containing compounds $\left(9 \%\right.$ of $\left.\mathrm{PM}_{1}\right)$ during these two periods based on HR-ToF-AMS results (X. Zhang et al., 2018), it is believed that aerosol transported to the Himalayas plays an important role in atmospheric radiative forcing.

Ramanathan and Carmichael (2008) found a distinct warming effect of light-absorbing aerosol over the Himalayas through estimating aerosol radiative forcing by $\mathrm{BC}$. However, brown carbon had not been considered before, which could also be an important light-absorbing aerosol due to its high mass loading (Laskin et al., 2015). Zhang et al. (2017) estimated the light absorption contribution of brown carbon from the inland Tibetan Plateau, which was up to $\sim 13 \%$ of that of $\mathrm{BC}$. The high DBE and nitrogencontaining OA in our study suggested aerosol in the Himalayas could also contain amounts of light-absorbing organic matter because the light absorption properties of organic molecules are closely related to the number of double bonds and rings in the molecule and nitrogen atoms. Many studies have found that the dominating chemical molecules in brown carbon were related to nitrogen-containing aerosol (e.g., Lin et al., 2016). This kind of aerosol combined with $\mathrm{BC}$ could have a higher radiative forcing than before in this area.

More comprehensive methods are needed in the future for identifying $\mathrm{BrC}$ in the Himalayas due to the chemical complexity of $\mathrm{BrC}$. For example, BrC extraction is highly dependent on the solvent used, and water-insoluble OA can contribute higher light absorption than water-soluble OA (Chen and Bond, 2010). In addition, Budisulistiorini et al. (2017) found that a number of compounds can dominate the light absorption of $\mathrm{BrC}$, although they make a minor contribution to the aerosol mass. Therefore, it is important to know the exact chromophores of $\mathrm{BrC}$ which can be obtained by combining light absorption measurement with a photodiode (PDA) detector and chemical composition with a highresolution mass spectrometer with high performance liquid chromatography (HPLC-PDA-HRMS system) (Lin et al., 2016). For mass spectrometry analysis, different ionization sources which are also favorable for different compounds, such as ESI, only detect a part of polar compounds; non-polar compounds which could dominate the contribution of $\mathrm{BrC}$ can be measured using atmospheric pressure photo ionization
(Lin et al., 2018). A recent study indicated that over $40 \%$ of the solvent-extractable $\mathrm{BrC}$ light absorption is attributed to water-insoluble, non-polar to semi-polar compounds such as PAHs and their derivatives (Lin et al., 2018). In contrast, the polar, water-soluble $\mathrm{BrC}$ compounds, which are detected in ESI, account for less than $30 \%$ of light absorption by $\mathrm{BrC}$ (Lin et al., 2018).

Data availability. The processed FTICR-MS data, AMS data, and meteorological data in this study are available upon request from the corresponding author (jzxu@lzb.ac.cn).

Author contributions. YA analyzed the data and wrote the manuscript. JX and SK organized the campaign, analyzed the data, and wrote the manuscript. LF, BJ, and YuL organized the mass spectrometry analysis. XZ analyzed AMS data and YaL collected the filter.

Competing interests. The authors declare that they have no conflict of interest.

Special issue statement. This article is part of the special issue "Study of ozone, aerosols and radiation over the Tibetan Plateau (SOAR-TP) (ACP/AMT inter-journal SI)". It is not associated with a conference.

Acknowledgements. This research was supported by grants from the National Natural Science Foundation of China (41771079, 41421061), the Key Laboratory of Cryospheric Sciences Scientific Research Foundation (SKLCS-ZZ-2018), and the Chinese Academy of Sciences Hundred Talents Program. The authors thank the QOMS for logistic support.

Edited by: Wenshou Tian

Reviewed by: three anonymous referees

\section{References}

Altieri, K. E., Turpin, B. J., and Seitzinger, S. P.: Composition of Dissolved Organic Nitrogen in Continental Precipitation Investigated by Ultra-High Resolution FT-ICR Mass Spectrometry, Environ. Sci. Technol., 43, 6950-6955, https://doi.org/10.1021/es9007849, 2009a.

Altieri, K. E., Turpin, B. J., and Seitzinger, S. P.: Oligomers, organosulfates, and nitrooxy organosulfates in rainwater identified by ultra-high resolution electrospray ionization FTICR mass spectrometry, Atmos. Chem. Phys., 9, 2533-2542, https://doi.org/10.5194/acp-9-2533-2009, 2009b.

Altieri, K. E., Hastings, M. G., Peters, A. J., and Sigman, D. M.: Molecular characterization of water soluble organic nitrogen in marine rainwater by ultra-high resolution electrospray ioniza- 
tion mass spectrometry, Atmos. Chem. Phys., 12, 3557-3571, https://doi.org/10.5194/acp-12-3557-2012, 2012.

Bonasoni, P., Laj, P., Marinoni, A., Sprenger, M., Angelini, F., Arduini, J., Bonafè, U., Calzolari, F., Colombo, T., Decesari, S., Di Biagio, C., di Sarra, A. G., Evangelisti, F., Duchi, R., Facchini, M. C., Fuzzi, S., Gobbi, G. P., Maione, M., Panday, A., Roccato, F., Sellegri, K., Venzac, H., Verza, G. P., Villani, P., Vuillermoz, E., and Cristofanelli, P.: Atmospheric Brown Clouds in the Himalayas: first two years of continuous observations at the Nepal Climate Observatory-Pyramid (5079 m), Atmos. Chem. Phys., 10, 7515-7531, https://doi.org/10.5194/acp10-7515-2010, 2010.

Budisulistiorini, S. H., Riva, M., Williams, M., Chen, J., Itoh, M., Surratt, J. D., and Kuwata, M.: Light-Absorbing Brown Carbon Aerosol Constituents from Combustion of Indonesian Peat and Biomass, Environ. Sci. Technol., 51, 4415-4423, https://doi.org/10.1021/acs.est.7b00397, 2017.

Canagaratna, M. R., Jimenez, J. L., Kroll, J. H., Chen, Q., Kessler, S. H., Massoli, P., Hildebrandt Ruiz, L., Fortner, E., Williams, L. R., Wilson, K. R., Surratt, J. D., Donahue, N. M., Jayne, J. T., and Worsnop, D. R.: Elemental ratio measurements of organic compounds using aerosol mass spectrometry: characterization, improved calibration, and implications, Atmos. Chem. Phys., 15, 253-272, https://doi.org/10.5194/acp-15-253-2015, 2015.

Chen, L.-W. A., Verburg, P., Shackelford, A., Zhu, D., Susfalk, R., Chow, J. C., and Watson, J. G.: Moisture effects on carbon and nitrogen emission from burning of wildland biomass, Atmos. Chem. Phys., 10, 6617-6625, https://doi.org/10.5194/acp10-6617-2010, 2010.

Chen, Y. and Bond, T. C.: Light absorption by organic carbon from wood combustion, Atmos. Chem. Phys., 10, 1773-1787, https://doi.org/10.5194/acp-10-1773-2010, 2010.

Choi, J. H., Ryu, J., Jeon, S., Seo, J., Yang, Y. H., Pack, S. P., Choung, S., and Jang, K. S.: In-depth compositional analysis of water-soluble and -insoluble organic substances in fine (PM2.5) airborne particles using ultra-high-resolution 15T FTICR MS and GCxGC-TOFMS, Environ. Pollut., 225, 329-337, https://doi.org/10.1016/j.envpol.2017.02.058, 2017.

Claeys, M., Szmigielski, R., Kourtchev, I., Van der Veken, P., Vermeylen, R., Maenhaut, W., Jaoui, M., Kleindienst, T. E., Lewandowski, M., Offenberg, J. H., and Edney, E. O.: Hydroxydicarboxylic Acids: Markers for Secondary Organic Aerosol from the Photooxidation of $\alpha$-Pinene, Environ. Sci. Technol., 41, 1628-1634, https://doi.org/10.1021/es0620181, 2007.

Cong, Z., Kawamura, K., Kang, S., and Fu, P.: Penetration of biomass-burning emissions from South Asia through the Himalayas: new insights from atmospheric organic acids, Sci. Rep.UK, 5, 9580, https://doi.org/10.1038/srep09580, 2015.

Cook, R. D., Lin, Y.-H., Peng, Z., Boone, E., Chu, R. K., Dukett, J. E., Gunsch, M. J., Zhang, W., Tolic, N., Laskin, A., and Pratt, K. A.: Biogenic, urban, and wildfire influences on the molecular composition of dissolved organic compounds in cloud water, Atmos. Chem. Phys., 17, 15167-15180, https://doi.org/10.5194/acp-17-15167-2017, 2017.

Cristofanelli, P., Bracci, A., Sprenger, M., Marinoni, A., Bonafè, U., Calzolari, F., Duchi, R., Laj, P., Pichon, J. M., Roccato, F., Venzac, H., Vuillermoz, E., and Bonasoni, P.: Tropospheric ozone variations at the Nepal Climate ObservatoryPyramid (Himalayas, $5079 \mathrm{~m}$ a.s.1.) and influence of deep strato- spheric intrusion events, Atmos. Chem. Phys., 10, 6537-6549, https://doi.org/10.5194/acp-10-6537-2010, 2010.

Draxler, R. R. and Hess, G. D.: An overview of the hysplit-4 modeling system for trajectories, Aust. Meteorol. Mag., 47, 295-308, 1998.

Dzepina, K., Mazzoleni, C., Fialho, P., China, S., Zhang, B., Owen, R. C., Helmig, D., Hueber, J., Kumar, S., Perlinger, J. A., Kramer, L. J., Dziobak, M. P., Ampadu, M. T., Olsen, S., Wuebbles, D. J., and Mazzoleni, L. R.: Molecular characterization of free tropospheric aerosol collected at the Pico Mountain Observatory: a case study with a long-range transported biomass burning plume, Atmos. Chem. Phys., 15, 5047-5068, https://doi.org/10.5194/acp-15-5047-2015, 2015.

Feng, L., Xu, J., Kang, S., Li, X., Li, Y., Jiang, B., and Shi, Q.: Chemical Composition of Microbe-Derived Dissolved Organic Matter in Cryoconite in Tibetan Plateau Glaciers: Insights from Fourier Transform Ion Cyclotron Resonance Mass Spectrometry Analysis, Environ. Sci. Technol., 50, 13215-13223, https://doi.org/10.1021/acs.est.6b03971, 2016.

Fleming, L. T., Lin, P., Laskin, A., Laskin, J., Weltman, R., Edwards, R. D., Arora, N. K., Yadav, A., Meinardi, S., Blake, D. R., Pillarisetti, A., Smith, K. R., and Nizkorodov, S. A.: Molecular composition of particulate matter emissions from dung and brushwood burning household cookstoves in Haryana, India, Atmos. Chem. Phys., 18, 2461-2480, https://doi.org/10.5194/acp18-2461-2018, 2018.

Gustafsson, Ö., Kruså, M., Zencak, Z., Sheesley, R. J., Granat, L., Engström, E., Praveen, P. S., Rao, P. S. P., Leck, C., and Rodhe, H.: Brown Clouds over South Asia: Biomass or Fossil Fuel Combustion?, Science, 323, 495-498, https://doi.org/10.1126/science.1164857, 2009.

Hughey, C. A., Hendrickson, C. L., Rodgers, R. P., Marshall, A. G., and Qian, K.: Kendrick Mass Defect Spectrum: A Compact Visual Analysis for Ultrahigh-Resolution Broadband Mass Spectra, Anal. Chem., 73, 4676-4681, https://doi.org/10.1021/ac010560w, 2001.

Iinuma, Y., Böge, O., Gräfe, R., and Herrmann, H.: MethylNitrocatechols: Atmospheric Tracer Compounds for Biomass Burning Secondary Organic Aerosols, Environ. Sci. Technol., 44, 8453-8459, https://doi.org/10.1021/es102938a, 2010.

Jayarathne, T., Stockwell, C. E., Bhave, P. V., Praveen, P. S., Rathnayake, C. M., Islam, Md. R., Panday, A. K., Adhikari, S., Maharjan, R., Goetz, J. D., DeCarlo, P. F., Saikawa, E., Yokelson, R. J., and Stone, E. A.: Nepal Ambient Monitoring and Source Testing Experiment (NAMaSTE): emissions of particulate matter from wood- and dung-fueled cooking fires, garbage and crop residue burning, brick kilns, and other sources, Atmos. Chem. Phys., 18, 2259-2286, https://doi.org/10.5194/acp18-2259-2018, 2018.

Kleindienst, T. E., Jaoui, M., Lewandowski, M., Offenberg, J. H., Lewis, C. W., Bhave, P. V., and Edney, E. O.: Estimates of the contributions of biogenic and anthropogenic hydrocarbons to secondary organic aerosol at a southeastern US location, Atmos. Environ., 41, 8288-8300, https://doi.org/10.1016/j.atmosenv.2007.06.045, 2007.

Koch, B. P. and Dittmar, T.: From mass to structure: an aromaticity index for high-resolution mass data of natural organic matter, Rapid Commun. Mass Spect., 20, 926-932, https://doi.org/10.1002/rcm.2386, 2006. 
Kristensen, K., Enggrob, K. L., King, S. M., Worton, D. R., Platt, S. M., Mortensen, R., Rosenoern, T., Surratt, J. D., Bilde, M., Goldstein, A. H., and Glasius, M.: Formation and occurrence of dimer esters of pinene oxidation products in atmospheric aerosols, Atmos. Chem. Phys., 13, 3763-3776, https://doi.org/10.5194/acp13-3763-2013, 2013.

Kroll, J. H., Donahue, N. M., Jimenez, J. L., Kessler, S. H., Canagaratna, M. R., Wilson, K. R., Altieri, K. E., Mazzoleni, L. R., Wozniak, A. S., Bluhm, H., Mysak, E. R., Smith, J. D., Kolb, C. E., and Worsnop, D. R.: Carbon oxidation state as a metric for describing the chemistry of atmospheric organic aerosol, Nat. Chem., 3, 133-139, https://doi.org/10.1038/nchem.948, 2011.

Laskin, A., Smith, J. S., and Laskin, J.: Molecular Characterization of Nitrogen-Containing Organic Compounds in Biomass Burning Aerosols Using High-Resolution Mass Spectrometry, Environ. Sci. Technol., 43, 3764-3771, https://doi.org/10.1021/es803456n, 2009.

Laskin, A., Laskin, J., and Nizkorodov, S. A.: Chemistry of Atmospheric Brown Carbon, Chem. Rev., 4335-4382, https://doi.org/10.1021/cr5006167, 2015.

Laskin, J., Laskin, A., and Nizkorodov, S. A.: Mass Spectrometry Analysis in Atmospheric Chemistry, Anal. Chem., 90, 166-189, 10.1021/acs.analchem.7b04249, 2018.

Lau, K. M., Kim, M. K., and Kim, K. M.: Asian summer monsoon anomalies induced by aerosol direct forcing: the role of the Tibetan Plateau, Clim. Dynam., 26, 855-864, https://doi.org/10.1007/s00382-006-0114-z, 2006.

Lee, B. H., Mohr, C., Lopez-Hilfiker, F. D., Lutz, A., Hallquist, M., Lee, L., Romer, P., Cohen, R. C., Iyer, S., Kurtén, T., Hu, W., Day, D. A., Campuzano-Jost, P., Jimenez, J. L., Xu, L., Ng, N. L., Guo, H., Weber, R. J., Wild, R. J., Brown, S. S., Koss, A., de Gouw, J., Olson, K., Goldstein, A. H., Seco, R., Kim, S., McAvey, K., Shepson, P. B., Starn, T., Baumann, K., Edgerton, E. S., Liu, J., Shilling, J. E., Miller, D. O., Brune, W., Schobesberger, S., D'Ambro, E. L., and Thornton, J. A.: Highly functionalized organic nitrates in the southeast United States: Contribution to secondary organic aerosol and reactive nitrogen budgets, P. Natl. Acad. Sci. USA, 113, 1516-1521, https://doi.org/10.1073/pnas.1508108113, 2016.

Lin, P., Rincon, A. G., Kalberer, M., and Yu, J. Z.: Elemental Composition of HULIS in the Pearl River Delta Region, China: Results Inferred from Positive and Negative Electrospray High Resolution Mass Spectrometric Data, Environ. Sci. Technol., 46, 7454-7462, https://doi.org/10.1021/es300285d, 2012.

Lin, P., Aiona, P. K., Li, Y., Shiraiwa, M., Laskin, J., Nizkorodov, S. A., and Laskin, A.: Molecular Characterization of Brown Carbon in Biomass Burning Aerosol Particles, Environ. Sci. Technol., 50, 11815-11824, https://doi.org/10.1021/acs.est.6b03024, 2016.

Lin, P., Bluvshtein, N., Rudich, Y., Nizkorodov, S. A., Laskin, J., and Laskin, A.: Molecular Chemistry of Atmospheric Brown Carbon Inferred from a Nationwide Biomass Burning Event, Environ. Sci. Technol., 51, 11561-11570, https://doi.org/10.1021/acs.est.7b02276, 2017.

Lin, P., Fleming, L. T., Nizkorodov, S. A., Laskin, J., and Laskin, A.: Comprehensive Molecular Characterization of Atmospheric Brown Carbon by High Resolution Mass Spectrometry with Electrospray and Atmospheric Pres- sure Photoionization, Anal. Chem., 90, 12493-12502, https://doi.org/10.1021/acs.analchem.8b02177, 2018.

Liu, Z., Liu, D., Huang, J., Vaughan, M., Uno, I., Sugimoto, N., Kittaka, C., Trepte, C., Wang, Z., Hostetler, C., and Winker, D.: Airborne dust distributions over the Tibetan Plateau and surrounding areas derived from the first year of CALIPSO lidar observations, Atmos. Chem. Phys., 8, 5045-5060, https://doi.org/10.5194/acp8-5045-2008, 2008.

Lu, Z., Streets, D. G., Zhang, Q., and Wang, S.: A novel backtrajectory analysis of the origin of black carbon transported to the Himalayas and Tibetan Plateau during 1996-2010, Geophys. Res. Lett., 39, L01809, https://doi.org/10.1029/2011g1049903, 2012.

Lüthi, Z. L., Škerlak, B., Kim, S.-W., Lauer, A., Mues, A., Rupakheti, M., and Kang, S.: Atmospheric brown clouds reach the Tibetan Plateau by crossing the Himalayas, Atmos. Chem. Phys., 15, 6007-6021, https://doi.org/10.5194/acp-156007-2015, 2015.

Mazzoleni, L. R., Ehrmann, B. M., Shen, X., Marshall, A. G., and Collett, J. L.: Water-Soluble Atmospheric Organic Matter in Fog: Exact Masses and Chemical Formula Identification by Ultrahigh-Resolution Fourier Transform Ion Cyclotron Resonance Mass Spectrometry, Environ. Sci. Technol., 44, 36903697, https://doi.org/10.1021/es903409k, 2010.

Mazzoleni, L. R., Saranjampour, P., Dalbec, M. M., Samburova, V., Hallar, A. G., Zielinska, B., Lowenthal, D. H., and Kohl, S.: Identification of water-soluble organic carbon in non-urban aerosols using ultrahigh-resolution FT-ICR mass spectrometry: organic anions, Environ. Chem., 9, 285, https://doi.org/10.1071/en11167, 2012.

Mead, R. N., Mullaugh, K. M., Brooks Avery, G., Kieber, R. J., Willey, J. D., and Podgorski, D. C.: Insights into dissolved organic matter complexity in rainwater from continental and coastal storms by ultrahigh resolution Fourier transform ion cyclotron resonance mass spectrometry, Atmos. Chem. Phys., 13, 48294838, https://doi.org/10.5194/acp-13-4829-2013, 2013.

Ng, N. L., Brown, S. S., Archibald, A. T., Atlas, E., Cohen, R. C., Crowley, J. N., Day, D. A., Donahue, N. M., Fry, J. L., Fuchs, H., Griffin, R. J., Guzman, M. I., Herrmann, H., Hodzic, A., Iinuma, Y., Jimenez, J. L., Kiendler-Scharr, A., Lee, B. H., Luecken, D. J., Mao, J., McLaren, R., Mutzel, A., Osthoff, H. D., Ouyang, B., Picquet-Varrault, B., Platt, U., Pye, H. O. T., Rudich, Y., Schwantes, R. H., Shiraiwa, M., Stutz, J., Thornton, J. A., Tilgner, A., Williams, B. J., and Zaveri, R. A.: Nitrate radicals and biogenic volatile organic compounds: oxidation, mechanisms, and organic aerosol, Atmos. Chem. Phys., 17, 2103-2162, https://doi.org/10.5194/acp-17-2103-2017, 2017.

O’Brien, R. E., Laskin, A., Laskin, J., Liu, S., Weber, R., Russell, L. M., and Goldstein, A. H.: Molecular characterization of organic aerosol using nanospray desorption/electrospray ionization mass spectrometry: CalNex 2010 field study, Atmos. Environ., 68, 265-272, https://doi.org/10.1016/j.atmosenv.2012.11.056, 2013.

Raeke, J., Lechtenfeld, O. J., Wagner, M., Herzsprung, P., and Reemtsma, T.: Selectivity of solid phase extraction of freshwater dissolved organic matter and its effect on ultrahigh resolution mass spectra, Environ. Sci. Process. Impacts, 18, 918-927, https://doi.org/10.1039/c6em00200e, 2016.

Ram, K., Sarin, M. M., and Hegde, P.: Long-term record of aerosol optical properties and chemical composition from a high- 
altitude site (Manora Peak) in Central Himalaya, Atmos. Chem. Phys., 10, 11791-11803, https://doi.org/10.5194/acp-10-117912010, 2010.

Ramanathan, V. and Carmichael, G.: Global and regional climate changes due to black carbon, Nat. Geosci., 1, 221-227, https://doi.org/10.1038/ngeo156, 2008.

Ramanathan, V., Ramana, M. V., Roberts, G., Kim, D., Corrigan, C., Chung, C., and Winker, D.: Warming trends in Asia amplified by brown cloud solar absorption, Nature, 448, 575-578, https://doi.org/10.1038/nature06019, 2007.

Roach, P. J., Laskin, J., and Laskin, A.: Higher-Order Mass Defect Analysis for Mass Spectra of Complex Organic Mixtures, Anal. Chem., 83, 4924-4929, https://doi.org/10.1021/ac200654j, 2011.

Saleh, R., Robinson, E. S., Tkacik, D. S., Ahern, A. T., Liu, S., Aiken, A. C., Sullivan, R. C., Presto, A. A., Dubey, M. K., Yokelson, R. J., Donahue, N. M., and Robinson, A. L.: Brownness of organics in aerosols from biomass burning linked to their black carbon content, Nat. Geosci., 7, 647-650, https://doi.org/10.1038/ngeo2220, 2014.

Schmitt-Kopplin, P., Liger-Belair, G., Koch, B. P., Flerus, R., Kattner, G., Harir, M., Kanawati, B., Lucio, M., Tziotis, D., Hertkorn, N., and Gebefügi, I.: Dissolved organic matter in sea spray: a transfer study from marine surface water to aerosols, Biogeosciences, 9, 1571-1582, https://doi.org/10.5194/bg-91571-2012, 2012.

Song, J., Li, M., Jiang, B., Wei, S., Fan, X., and Peng, P. A.: Molecular Characterization of Water-Soluble Humic like Substances in Smoke Particles Emitted from Combustion of Biomass Materials and Coal Using Ultrahigh-Resolution Electrospray Ionization Fourier Transform Ion Cyclotron Resonance Mass Spectrometry, Environ. Sci. Technol., 52, 2575-2585, https://doi.org/10.1021/acs.est.7b06126, 2018.

Stockwell, C. E., Christian, T. J., Goetz, J. D., Jayarathne, T., Bhave, P. V., Praveen, P. S., Adhikari, S., Maharjan, R., DeCarlo, P. F., Stone, E. A., Saikawa, E., Blake, D. R., Simpson, I. J., Yokelson, R. J., and Panday, A. K.: Nepal Ambient Monitoring and Source Testing Experiment (NAMaSTE): emissions of trace gases and light-absorbing carbon from wood and dung cooking fires, garbage and crop residue burning, brick kilns, and other sources, Atmos. Chem. Phys., 16, 11043-11081, https://doi.org/10.5194/acp-16-11043-2016, 2016.

Stone, E. A., Nguyen, T. T., Pradhan, B. B., and Man Dangol, P.: Assessment of biogenic secondary organic aerosol in the Himalayas, Environ. Chem., 9, 263-272, https://doi.org/10.1071/EN12002, 2012.

Sun, Y. L., Zhang, Q., Anastasio, C., and Sun, J.: Insights into secondary organic aerosol formed via aqueous-phase reactions of phenolic compounds based on high resolution mass spectrometry, Atmos. Chem. Phys., 10, 4809-4822, https://doi.org/10.5194/acp-10-4809-2010, 2010.

Wan, E. C. H. and Yu, J. Z.: Determination of sugar compounds in atmospheric aerosols by liquid chromatography combined with positive electrospray ionization mass spectrometry, J. Chromatogr. A, 1107, 175-181, https://doi.org/10.1016/j.chroma.2005.12.062, 2006.

Wang, X., Gong, P., Sheng, J., Joswiak, D. R., and Yao, T.: Long-range atmospheric transport of particulate Polycyclic Aromatic Hydrocarbons and the incursion of aerosols to the southeast Tibetan Plateau, Atmos. Environ., 115, 124-131, https://doi.org/10.1016/j.atmosenv.2015.04.050, 2015.

Wang, X., Ren, J., Gong, P., Wang, C., Xue, Y., Yao, T., and Lohmann, R.: Spatial distribution of the persistent organic pollutants across the Tibetan Plateau and its linkage with the climate systems: a 5-year air monitoring study, Atmos. Chem. Phys., 16 , 6901-6911, https://doi.org/10.5194/acp-16-6901-2016, 2016.

Wang, Y., Hu, M., Lin, P., Guo, Q., Wu, Z., Li, M., Zeng, L., Song, Y., Zeng, L., Wu, Y., Guo, S., Huang, X., and He, L.: Molecular Characterization of Nitrogen-Containing Organic Compounds in Humic-like Substances Emitted from Straw Residue Burning, Environ. Sci. Technol., 51, 5951-5961, https://doi.org/10.1021/acs.est.7b00248, 2017.

Washenfelder, R. A., Attwood, A. R., Brock, C. A., Guo, H., Xu, L., Weber, R. J., Ng, N. L., Allen, H. M., Ayres, B. R., Baumann, K., Cohen, R. C., Draper, D. C., Duffey, K. C., Edgerton, E., Fry, J. L., Hu, W. W., Jimenez, J. L., Palm, B. B., Romer, P., Stone, E. A., Wooldridge, P. J., and Brown, S. S.: Biomass burning dominates brown carbon absorption in the rural southeastern United States, Geophys. Res. Lett., 42, 653-664, https://doi.org/10.1002/2014GL062444, 2015.

Wozniak, A. S., Bauer, J. E., Sleighter, R. L., Dickhut, R. M., and Hatcher, P. G.: Technical Note: Molecular characterization of aerosol-derived water soluble organic carbon using ultrahigh resolution electrospray ionization Fourier transform ion cyclotron resonance mass spectrometry, Atmos. Chem. Phys., 8, 50995111, https://doi.org/10.5194/acp-8-5099-2008, 2008.

Wozniak, A. S., Willoughby, A. S., Gurganus, S. C., and Hatcher, P. G.: Distinguishing molecular characteristics of aerosol water soluble organic matter from the 2011 trans-North Atlantic US GEOTRACES cruise, Atmos. Chem. Phys., 14, 8419-8434, https://doi.org/10.5194/acp-14-8419-2014, 2014.

Wu, Z., Rodgers, R. P., and Marshall, A. G.: Two- and three-dimensional van krevelen diagrams: a graphical analysis complementary to the kendrick mass plot for sorting elemental compositions of complex organic mixtures based on ultrahigh-resolution broadband fourier transform ion cyclotron resonance, Anal. Chem., 76, 2511-2516, https://doi.org/10.1021/ac0355449, 2004.

Xia, X., Zong, X., Cong, Z., Chen, H., Kang, S., and Wang, P.: Baseline continental aerosol over the central Tibetan plateau and a case study of aerosol transport from South Asia, Atmos. Environ., 45, 7370-7378, https://doi.org/10.1016/j.atmosenv.2011.07.067, 2011.

Xu, J., Zhang, Q., Shi, J., Ge, X., Xie, C., Wang, J., Kang, S., Zhang, R., and Wang, Y.: Chemical characteristics of submicron particles at the central Tibetan Plateau: insights from aerosol mass spectrometry, Atmos. Chem. Phys., 18, 427-443, https://doi.org/10.5194/acp-18-427-2018, 2018.

Xu, L., Guo, H., Boyd, C. M., Klein, M., Bougiatioti, A., Cerully, K. M., Hite, J. R., Isaacman-VanWertz, G., Kreisberg, N. M., Knote, C., Olson, K., Koss, A., Goldstein, A. H., Hering, S. V., de Gouw, J., Baumann, K., Lee, S.-H., Nenes, A., Weber, R. J., and $\mathrm{Ng}, \mathrm{N}$. L.: Effects of anthropogenic emissions on aerosol formation from isoprene and monoterpenes in the southeastern United States, P. Natl. Acad. Sci. USA, 112, 37-42, https://doi.org/10.1073/pnas.1417609112, 2014.

Yu, L., Smith, J., Laskin, A., Anastasio, C., Laskin, J., and Zhang, Q.: Chemical characterization of SOA formed from aqueous- 
phase reactions of phenols with the triplet excited state of carbonyl and hydroxyl radical, Atmos. Chem. Phys., 14, 1380113816, https://doi.org/10.5194/acp-14-13801-2014, 2014.

Yu, L., Smith, J., Laskin, A., George, K. M., Anastasio, C., Laskin, J., Dillner, A. M., and Zhang, Q.: Molecular transformations of phenolic SOA during photochemical aging in the aqueous phase: competition among oligomerization, functionalization, and fragmentation, Atmos. Chem. Phys., 16, 4511-4527, https://doi.org/10.5194/acp-16-4511-2016, 2016.

Zhang, H., Yee, L. D., Lee, B. H., Curtis, M. P., Worton, D. R., Isaacman-VanWertz, G., Offenberg, J. H., Lewandowski, M., Kleindienst, T. E., Beaver, M. R., Holder, A. L., Lonneman, W. A., Docherty, K. S., Jaoui, M., Pye, H. O. T., Hu, W., Day, D. A., Campuzano-Jost, P., Jimenez, J. L., Guo, H., Weber, R. J., de Gouw, J., Koss, A. R., Edgerton, E. S., Brune, W., Mohr, C., Lopez-Hilfiker, F. D., Lutz, A., Kreisberg, N. M., Spielman, S. R., Hering, S. V., Wilson, K. R., Thornton, J. A., and Goldstein, A. H.: Monoterpenes are the largest source of summertime organic aerosol in the southeastern United States, P. Natl. Acad. Sci. USA, 115, 2038-2043, https://doi.org/10.1073/pnas.1717513115, 2018.

Zhang, Q., Canagaratna, M. R., Jayne, J. T., Worsnop, D. R., and Jimenez, J. L.: Time- and size-resolved chemical composition of submicron particles in Pittsburgh: Implications for aerosol sources and processes, J. Geophys. Res., 110, D07S09, https://doi.org/10.1029/2004jd004649, 2005.
Zhang, R., Wang, H., Qian, Y., Rasch, P. J., Easter, R. C., Ma, P.L., Singh, B., Huang, J., and Fu, Q.: Quantifying sources, transport, deposition, and radiative forcing of black carbon over the Himalayas and Tibetan Plateau, Atmos. Chem. Phys., 15, 62056223, https://doi.org/10.5194/acp-15-6205-2015, 2015.

Zhang, X., Xu, J., Kang, S., Liu, Y., and Zhang, Q.: Chemical characterization of long-range transport biomass burning emissions to the Himalayas: insights from high-resolution aerosol mass spectrometry, Atmos. Chem. Phys., 18, 4617-4638, https://doi.org/10.5194/acp-18-4617-2018, 2018.

Zhang, Y., Xu, J., Shi, J., Xie, C., Ge, X., Wang, J., Kang, S., and Zhang, Q.: Light absorption by water-soluble organic carbon in atmospheric fine particles in the central Tibetan Plateau, Environ. Sci. Pollut. Res., 24, 21386-21397, https://doi.org/10.1007/s11356-017-9688-8, 2017.

Zhao, Y., Hallar, A. G., and Mazzoleni, L. R.: Atmospheric organic matter in clouds: exact masses and molecular formula identification using ultrahigh-resolution FT-ICR mass spectrometry, Atmos. Chem. Phys., 13, 12343-12362, https://doi.org/10.5194/acp-13-12343-2013, 2013. 